\title{
フラクタルカインと炎症性疾患
}

今井俊 夫*1, 西村美由希*1, 南木敏 宏*2, 梅原久 範*3

\section{Fractalkine and inflammatory diseases}

\author{
Toshio IMAI $^{* 1}$, Miyuki NishImURA ${ }^{* 1}$, Toshihiro NANKI ${ }^{* 2}$ and Hisanori UMEHARA*3 \\ ${ }^{*}{ }_{1} \mathrm{KAN}$ Research Institute \\ ${ }^{*}$ Department of Medicine and Rheumatology, Graduate School, Tokyo Medical and Dental University \\ ${ }^{*}$ Division of Hematology and Immunology, Department of Internal Medicine, Kanazawa Medical University
}

(Received April 6, 2005)

summary

The migration of leukocytes into inflamed peripheral tissues and lymphoid organs involves a cascade of molecular events finely regulated by cell adhesion molecules and chemokines. Fractalkine/CX3CL1 is a membrane-bound chemokine that functions not only as a chemoattractant but also as an adhesion molecule, and is expressed on endothelial cells activated by proinflammatory cytokines. The fractalkine receptor, CX3CR1, is expressed on cytotoxic effector lymphocytes including NK cells and cytotoxic effector $\mathrm{T}$ cells $\left(\mathrm{T}_{\mathrm{CE}}\right)$, mature monocytes/macrophages, and mucosal dendritic cells, all of which play important roles in elimination of pathogens and cancer cells. Recently, accumulating evidence in both clinical studies and animal disease models has shown that fractalkine is also involved in the pathogenesis of various chronic inflammatory diseases, such as rheumatoid arthritis and atherosclerosis. This article reviews the unique functions of fractalkine and its pathophysiological roles in various clinical conditions.

Key words_— cell migration; fractalkine/CX3CL1; cytotoxic lymphocytes; mucosal immunity; chronic inflammatory disease

\section{抄録}

炎症や免疫反応は生体局所で生じることから明らかなように，免疫細胞の時空間的局在は緻密に制御されてい る. 免疫細胞は細胞接着分子と細胞遊走因子を巧みに利用して, 炎症部位やリンパ組織に到達する. フラクタルカ イン/CX3CL1 は，ケモカインと細胞接着分子の 2 つの活性を併せ持ち，活性化血管内皮細胞上に発現する細胞膜 結合型ケモカインである。その受容体 CX3CR1 は, NK 細胞や cytotoxic effector $\mathrm{T}$ 細胞 $\left(\mathrm{T}_{\mathrm{CE}}\right)$ などの細胞傷害性 リンパ球と成熟マクロファージや粘膜樹状細胞などの病原体や異常な細胞の排除に深く関わる免疫細胞に発現して いる. 最近の臨床病態やマウス疾患モデルでの研究から, フラクタルカインは, 関節リウマチや弹状動脈硬化症な ぞの慢性炎症疾患にも深く関与していることが示唆されている. 本稿では, フラクタルカインの特徵的な機能と炎 症疾患における役割について概説する.

\section{はじめに}

免疫細胞は，異物の進入や組織の損傷などの異常 を監視するために，常に血管を通じて全身を移動し ている.また，組織中の抗原や免疫細胞は, リンパ 管を経由してリンパ組織に集積され，効率よい免疫 反応とその調節が可能となる，免疫応答は，外敵の 排除には必須の機能である反面, 自己への過剰な応 答を開始すると様々な自己免疫疾患を誘発する。多

\footnotetext{
*1 カン研究所

*2東京医科歯科大学大学院 膠原病・リウマチ内科学

*3 金沢医科大学 血液免疫制御学
}

くの自己免疫疾患では, 血管傷害や免疫細胞の浸潤 が病巣部で認められ, 免疫細胞の分化, 増殖, 細胞 死を制御するメカニズムの解明とその疾患治療への 応用が研究されている. さらに最近の研究から, 細 胞の生死に加え, 生体局所への細胞局在, すなわ ち, 免疫細胞の組織への浸潤・集積とリンパ組織や 血流への移動も, 免疫反応の強弱を決定する因子と して重要な役割を果たしていることが明らかとなつ てきている.

免疫細胞の血管内皮細胞を経由する組織浸潤過程 は，多くの接着分子と細胞遊走因子によって病態や 状況に応じて巧妙に制御されている1〜4)（図 1a）。 
免疫細胞が組織に浸潤するには，まず血管内皮細胞 という障壁を通過する必要がある，免疫細胞は，セ レクチンなどの弱い結合の接着分子によりコロコロ と転がるように内皮細胞との接触を繰り返し，血管 内皮上に提示されたケモカインなどの遊走因子を サーチする (rolling)。分泌型のケモカインは, へ パリン硫酸プロテオグリカンに結合して内皮細胞上 に提示され，血中での濃度勾配を保っている．免疫 細胞がケモカインを認識すると, 活性化シグナルが 伝達される (triggering)。続いて，インテグリンの コンフォメーション変化や集積が生じ, 免疫細胞 は，血管内皮細胞と強固に接着して細胞移動を停止 する (firm adhesion). その後, 免疫細胞は, 内皮 細胞間隙に移動して内皮細胞のジャンクションを局 所的に破壊して, 内皮細胞間隙を経由して組織内に 浸潤する (transmigration)。

免疫細胞の移動は, 血管外浸出による炎症部位へ の集積に限らず，リンパ管を経由した樹状細胞や T 細胞の所属リンパ組織への移行, 好中球や好酸球お よび $\mathrm{T}$ 細胞の腸管や気道の上皮細胞バリアーを経 由した体腔外への浸出などでも見られる。これら組 織への移入, 滞留, 移出は, 遅滞なく整合性を持つ て行なわれる必要がある。細胞の移動動態は, 薬物 の体内動態と同様のコンパートメントモデルが適応 できると考えられる.

ケモカインは, このような免疫反応のダイナミク スを決定する機構で重要な役割をはたしている。 フ ラクタルカインは活性化内皮細胞に発現する膜結合 型ケモカインで，ケモカインとしての細胞遊走活性 と接着分子としての機能をあわせもつユニークな分 子である。本稿では, フラクタルカインの生物学的 役割と炎症疾患への関与について概説する。

\section{1. フラクタルカイン/CX3CL1 と CX3CR1 の特徵}

\section{フラクタルカインの構造と発現}

フラクタルカインは, 1997 年に EST データベー スの検索により発見された膜結合型ケモカインであ る5). 約 50 種類あるケモカインは, $\mathrm{N}$ 末端の残基 の配列により $\mathrm{CC}, \mathrm{CXC}, \mathrm{CX} 3 \mathrm{C}, \mathrm{C}$ サブファミリー に分類される ${ }^{6}$. 他のケモカインが分泌蛋白質であ るのに対して，フラクタルカインと SR-PSOX/ CXCL16の 2 つは, 膜蛋白質として産生される. フラクタルカインは, $\mathrm{N}$ 末側から, ケモカインド メイン, ムチンドメイン, 膜貫通ドメイン, 細胞内 ドメインという構造をとつている（図 2).ムチン
ドメインは, 約 $29 \mathrm{~nm}$ の棒状の構造をしており, ケモカインドメインを細胞膜表面に提示する機能を 果たしている7.

フラクタルカインは，血管内皮細胞では，LPS， TNF- $\alpha$, IL-1, IFN- $\gamma$, CD 40L などの炎症性刺激で 発現が誘導される。一方，IL-4 や IL-13 などの type 2 サイトカインは, TNF- $\alpha$ と IFN- $\gamma$ による発 現誘導を抑制する ${ }^{8,9)}$. フラクタルカインは, 樹状 細胞, ニューロン, 活性化アストロサイトでも発現 する.また, 膵臓 $\beta$ 細胞, 腎メサンギウム細胞, 気道や尿細管および腸管上皮細胞でも, 炎症性サイ トカインによって発現が誘導される. その他, 癌抑 制遺伝子 p 53 は, 直接フラクタルカインのプロ モーターに結合し発現を誘導することが報告されて いる10).

膜結合型のフラクタルカインは, 細胞外領域がメ タロプロテアーゼにより切断（シェディング）され 分泌型となる. シェディングには, disintegrin-like metalloproteinase 10 (ADAM10) が恒常的に, TNF $\alpha$-converting enzyme (TACE; ADAM17) が刺 激時に働いている11,12). 分泌型フラクタルカインは, $\mathrm{NK}$ 細胞, $\mathrm{T}$ 細胞, 単球に対する細胞遊走活性を示 す, $4,5,13)$.

フラクタルカインの受容体 CX3CR1 は, 他のケ モカインと同様に 7 回膜貫通 $\mathrm{G}$ 蛋白共役型受容体 ファミリーに属する6,13). CX3CR1 は, 単球, リン パ球，樹状細胞で発現するほか，ニューロン，ミク ログリア，関節滑膜線維芽細胞などで発現してい る. ヒト CX3CR1 遺伝子には 6 番目の膜貫通部位 にあるアミノ酸 294 番目の Val が Iln（I249）に， 7 番目の膜貫通部位にあるアミノ酸 280 番目の $\mathrm{Thr}$ が Met（M280）に変異する2つの polymorphism が存在する. これらの変異は, 後述のように心血管 疾患や AIDS 発症のリスクと相関することが示さ れている14,15).

\section{細胞接着分子としてのフラクタルカインと CX3CR1}

われわれは，フラクタルカイン受容体 (CX3CR1) を同定し, 膜結合型フラクタルカインと CX3CR1 の相互作用が, 他の接着分子の力を借りずにその結 合力だけで細胞接着をひき起こすことを明らかにし た $3,4,13)$ (図 2)。CX3CR1 を発現する細胞は，イン テグリンやセレクチンの接着活性に依存することな く膜結合型フラクタルカインへ接着する. フラクタ 
$\begin{array}{lll}\text { (a) Rolling } & \text { Triggering } \\ & & \end{array}$

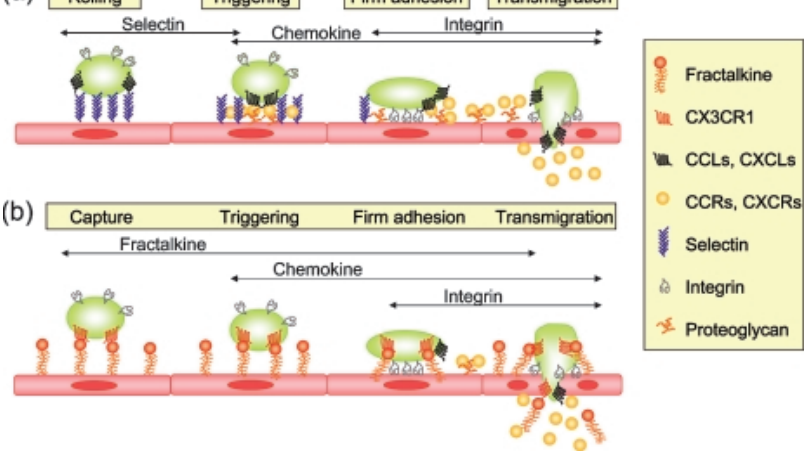

図 1 典型的ケモカインとフラクタルカインによる細胞浸潤 （a）血流中の免疫細胞は，セレクチンによるローリング，ケ モカインによる活性化，インテグリンによる強固な接着を経 て, 内皮細胞間隙から組織に浸潤する。（b) フラクタルカイ ンによる細胞浸潤は，フラクタルカインのみで血流中の免疫 細胞の捕獲から接着までのステップを遂行できる．同時に， 典型的なケモカインと同様にインテグリンの活性化を介した 接着も誘導する.

(a)

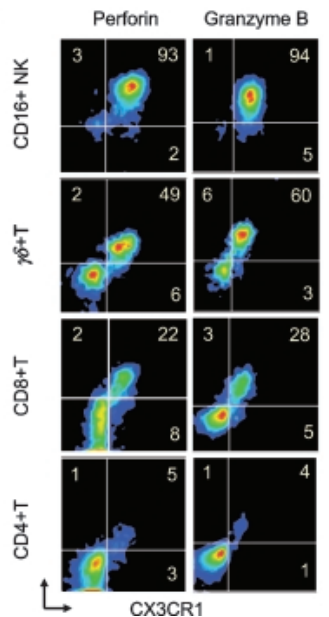

(b)

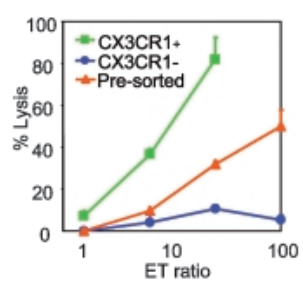

(c)

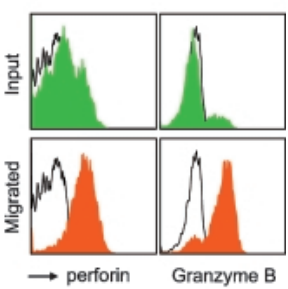

図 3 ヒト末梢血における CX3CR1 発現細胞の特性 (a) CX3CR1 は, $\mathrm{CD} 16^{+} \mathrm{NK}$ 細胞, $\gamma \delta^{+} \mathrm{T}$ 細胞, $\mathrm{CD} 8^{+} \mathrm{T}$ 細 胞, $\mathrm{CD} 4^{+} \mathrm{T}$ 細胞いずれの細胞においても, perforin や granzyme B 陽性のキラーリンパ球に選択的に発現する。(b) $\mathrm{CD}^{+} \mathrm{T}$ 細胞では, $\mathrm{CX} 3 \mathrm{CR} 1^{+}$細胞分画のみに著明な細胞傷 害活性が認められる。 (c) 分泌型フラクタルカインは, perforin や granzyme B 陽性のキラーリンパ球を選択的に遊走 させる。

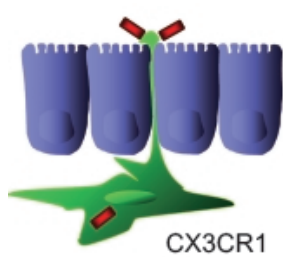

Lamina propria

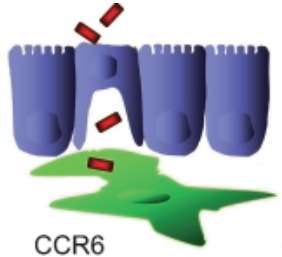

Payer's patch

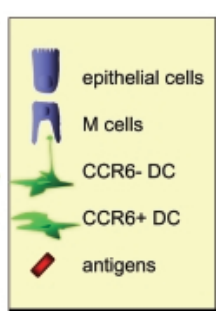

図 5 腸管での樹状細胞による抗原の捕獲 粘膜固有層の骨髄系樹状細胞は, CX3CR1 依存性に腸管 上皮細胞間隙に樹状突起を貫入して，腸管内腔に存在する細 菌（抗原）を採取する。一方，パイエル板での $\mathrm{M}$ 細胞経由 の細菌（抗原）採取は, CX3CR1に依存していない.

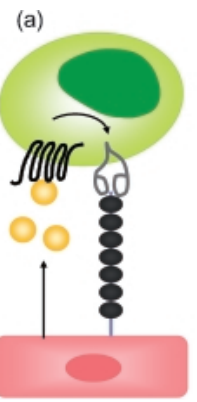

(b)

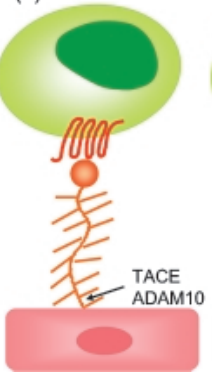

(c)

図 2 フラクタルカインによる多様な細胞接着 (a)典型的なケモカインは, インテグリンを活性化して細胞 接着を誘導する。（b)膜結合型フラクタルカインは, CX3CR1 との直接結合により細胞接着を成し得る. 膜結合 型フラクタルカインは, TACE P ADAM10 によりシェディ ングされる. (c)膜結合型フラクタルカインは, インテグリ ンを活性化して細胞接着を相加的に増強する。

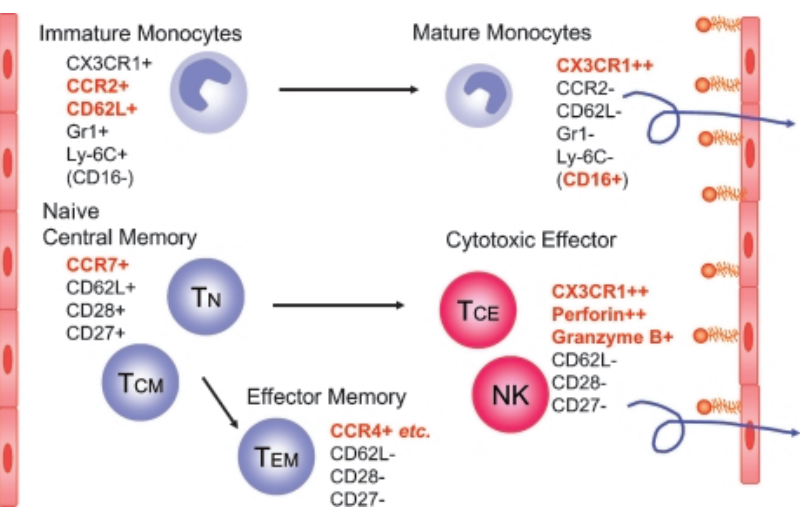

図 4 フラクタルカインに応答する $\mathrm{CX} 3 \mathrm{CR} 1^{+}$細胞集団 フラクタルカインは, $\mathrm{CD} 16^{+} \mathrm{Gr} 1^{-}$の成熟単球と $\mathrm{CCR} 7$ CD27-CD28-の最終分化したエフェクター細胞のなかで perforin $^{+}$granzyme B $\mathrm{B}^{+}$の細胞傷害活性を有する cytotoxic effector $\mathrm{T}$ 細胞 $\left(\mathrm{T}_{\mathrm{CE}}\right)$ と $\mathrm{NK}$ 細胞の細胞浸潤に関与する.

ルカイン-CX3CR1 による接着は，フラクタルカイ ンのケモカインドメインと CX3CR1 の直接結合だ けで細胞接着に必要な強度は十分であり, シグナル 伝達は必要ない13). 従来, ケモカインは, ケモカイ ン受容体を介してインテグリンを活性化し細胞接着 を誘導すると考えられており, 膜結合型フラクタル カインと 7 回膜貫通型 CX3CR1 が直接接着分子と して機能し得ることは驚きであった。 さらに, 膜結 合型フラクタルカインは, CX3CR1 を介してイン テグリンを活性化して ICAM-1 やフィブロネクチ ンへの接着を誘導し, 細胞接着を相加的に増強す る16)（図 2)。ケモカイン刺激によるインテグリン を介した細胞接着は通常一過性であるが, フラクタ ルカイン-CX3CR1 の接着は安定であり, 接着の解 除はメタロプロテアーゼによるシェディングによる 
と考えられている17).

生理的流速条件下でも，セレクチンやインテグリ ンや $\mathrm{G}$ 蛋白質に依存せず，フラクタルカインは単 独であるいは VCAM-1 と相乗的に CX3CR $1^{+}$細胞 を捕獲し接着させることができる3,4,18)（図 1b)。流 速下での捕獲と接着には，CX3CR1 のアミノ酸 14 番目 Tyr の硫酸化が必須であり，この硫酸化によ りフラクタルカインに対する結合親和性が 100 倍上 昇する ${ }^{19)}$. 膜結合型フラクタルカインと CX3CR1 による接着は，従来の細胞浸潤において，セレクチ ン, ケモカイン, インテグリンが関与する 3 つの分 子間相互作用が必要な複雑な反応を単独で行うシン プルな極めて効率の良い接着機構である.

\section{2. フラクタルカイン-CX3CR1 系の各種免疫細胞 での機能}

\section{キラー細胞の活性化と浸潤増幅機構}

ケモカイン受容体の発現は, 成熟段階やリンパ球 のサブセットによる組織指向性と密接に関係してい る。Th1 細胞には CCR 5 や CXCR3 が，Th2 には CCR4 が発現していることが知られている。 メモ リー $\mathrm{T}$ 細胞は, リンパ組織に移行する $\mathrm{CCR} 7^{+}$の central memory $\mathrm{T}$ 細胞 $\left(\mathrm{T}_{\mathrm{CM}}\right)$ と末梢組織に浸潤し てサイトカイン産生を行う CCR7-の effector memory $\mathrm{T}$ 細胞（ $\mathrm{T}_{\mathrm{EM}} ）$ に細分される.

最近われわれは，新たに作製したモノクローナル 抗体を用いてヒト末梢血リンパ球での CX3CR1の 発現を詳細に解析し, CX3CR1 が細胞傷害活性を 持つキラーリンパ球に特異的に発現していることを 明らかにした20)（図 3)。CX3CR1 は，CD16+ NK 細胞の大部分と $\mathrm{CD} 4^{+} \mathrm{T}$ 細胞, $\mathrm{CD} 8^{+} \mathrm{T}$ 細胞, $\gamma \delta^{+}$ $\mathrm{T}$ 細胞の一部で発現しており,これら $\mathrm{CX} 3 \mathrm{CR} 1^{+}$ 細胞はキラー活性に関与する perforin や granzyme B を発現している細胞と一致していた。末梢血 $\mathrm{CD} 8{ }^{+} \mathrm{T}$ 細胞を CX3CR1 発現の有無でソーティン グし細胞傷害活性を比較したところ, CX $3 \mathrm{CR} 1^{+}$細 胞分画にのみ著明な細胞傷害活性が認められた。

$\mathrm{T}$ 細胞では, CX3CR1 は CCR7 ${ }^{-} \mathrm{CD} 27^{-} \mathrm{CD} 28^{-}$の effector memory $\mathrm{T}$ 細胞でかつ細胞傷害活性を有す る cytotoxic effector $\mathrm{T}$ 細胞 $\left(\mathrm{T}_{\mathrm{CE}}\right)$ に発現している ことが明らかとなった。一方, 分泌型フラクタルカ インは，キラーリンパ球を選択的に遊走させ，内皮 細胞上に発現した膜結合型フラクタルカインは, MIP-1 $\alpha$ や IL-8 など他の二次性ケモカインによる キラーリンパ球の浸潤を選択的に増強した ${ }^{20)}$. した
がって, CX3CR1 は, ケモカイン受容体のなかで もエフェクターキラーリンパ球に特異的に発現する ユニークな受容体であり, フラクタルカインは, 血 流中から選択的かつ効率よくキラーリンパ球を捕獲 して速やかかつ選択的に炎症組織に浸潤させる門番 (ゲートキーパー）として機能していると考えられ る.

フラクタルカインは, キラーリンパ球とりわけ $\mathrm{NK}$ 細胞の活性化を誘導する. 分泌型フラクタルカ インは, NK 細胞からの perforin や granzyme など が含まれる細胞傷害性顆粒の放出を誘導する21)。ま た, 膜結合型フラクタルカインを発現させた内皮細 胞は, CX3CR1 依存性に NK 細胞との接着が増強 し， NK 細胞による細胞傷害を受けやすくなる。し たがって，フラクタルカインは， $\mathrm{NK}$ 細胞を活性化 する因子として機能していると考えられる4,21). さ らに, 膜結合型フラクタルカインは, $\mathrm{NK}$ 細胞上の CX3CR1 を架橋することで, チロシンキナーゼお よび PI-3 キナーゼ依存性に IFN- $\gamma$ の産生を誘導す る22). 分泌型フラクタルカインではこのような効果 は見られない. 活性化内皮細胞上のフラクタルカイ ンに NK 細胞が接着し活性化された後, 組織中で IFN- $\gamma$ を産生することで, さらに内皮細胞でのフ ラクタルカインの発現が誘導され, NK 細胞自身や 細胞傷害性 $\mathrm{T}$ 細胞の遊走を増強するというポジテ イブフィードバック機構として働くことが示唆され る ${ }^{4,22)}$.

\section{成熟単球の恒常的組織浸潤}

フラクタルカインは, 単球の遊走やインテグリン 非依存性の接着を誘導する。つい最近になって, フ ラクタルカインは, 単球のなかでも特徵的な集団の 接着および遊走を選択的に誘導することが示され た ${ }^{23,24)}$ (図 4).ヒト単球は, 大きく2つの集団, $\mathrm{CD} 14^{10} \mathrm{CD} 16^{+}$と $\mathrm{CD} 14^{+} \mathrm{CD} 16^{-}$に分類される。 $\mathrm{CD} 14^{\mathrm{lo}} \mathrm{CD} 16^{+}$単球は, $\mathrm{CX} 3 \mathrm{CR} 1^{\mathrm{hi}} \mathrm{CCR} 2^{-}$であり, フラクタルカインに対して選択的に反応する. 一方, $\mathrm{CD} 14^{+} \mathrm{CD} 16^{-}$単球は, $\mathrm{CX} 3 \mathrm{CR} 1^{\mathrm{lo}} \mathrm{CCR} 2^{+}$であり, MCP-1 など炎症性ケモカインに対して選択的に反 応する. マウスでも単球は, 恒常的に末梢組織に浸 潤する CX3CR $1{ }^{\mathrm{hi} C C R} 2^{-} \mathrm{Gr} 1^{-}$常在性サブセット と, 炎症組織にすみやかに浸潤して直接炎症反応に 関与する短寿命の $\mathrm{CX} 3 \mathrm{CR} 1{ }^{10} \mathrm{CCR} 2+\mathrm{Gr} 1^{+}$炎症性サ ブセットの 2 つ大きく分類されることが報告され た ${ }^{23)}$. さらに, CX3CR1 ノックインマウスの解析 
によって，CX3CR1 は，常在性サブセットの恒常 的な末梢組織への浸潤にかかわり，急性炎症部位へ の炎症性サブセットの組織浸潤には関与していない ことが明らかとなった。一方, clodronate リポソー ムによって in vivo で単球を除去した後の単球の再 増殖過程を調べた結果から, $\mathrm{Gr} 1^{+} \mathrm{Ly} 6 \mathrm{C}^{+}$の未熟な 単球から $\mathrm{Gr} 1^{-} \mathrm{Ly} 6 \mathrm{C}^{-}$のより成熟した単球へ分化す ることが示された ${ }^{25)}$. これらの結果を考え合わせる と，より成熟した単球は CX3CR $1^{\mathrm{hi}}$ で血液中での保 持がよく恒常的に組織に浸潤し，未熟な単球は CX3CR1 以外の CCR2 などのケモカイン受容体を 用いて急性炎症時に末梢組織へ速やかに移行すると 考えられる。一方, 関節リウマチなどの慢性炎症性 疾患患者では, $\mathrm{CD} 14^{1 \circ} \mathrm{CD} 16^{+}$サブセットが血液中 で増加し, これらが炎症性単球と呼ばれる場合があ る. ヒトとマウスでは全く別の集団が炎症性単球と 呼称されて混乱している。これは, マウスでは急性 炎症時に動員される未熟な単球を炎症性として, ヒ トでは慢性炎症時に増加する成熟した単球を炎症性 として定義されているためであり，未熟単球と成熟 単球に用語を統一すると考えやすい. 後述のよう に，最近われわれは関節リウマチなどの慢性炎症時 には, フラクタルカイン-CX3CR1 系が病態形成に 重要な役割を果たしていることを明らかにしている.

\section{骨髄系粘膜樹状細胞による腸管抗原の捕獲}

2000 年に作製された CX3CR1 ノックアウトマウ スでは, マクロファージや樹状細胞の浸潤や活性化 には大きな影響がないとされていたが26)，つい最近 になって腸管の粘膜樹状細胞による抗原捕捉機能に 重要な機能を果たしていることが明らかにされた27) (図 5)。CX3CR1 ノックアウトマウスでは, 小腸の 粘膜固有層への骨髄系粘膜樹状細胞の浸潤に変化は ないが，腸管上皮細胞間隙を貫いて樹状突起を進展 し腸管内腔に存在する細菌を採取する機能が消失し ていた，興味深いことに，フラクタルカインの上皮 細胞での発現は小腸終末部で強く, 樹状突起が見ら れる部位および腸内細菌の密度が濃い部位と一致し ていた。 CX3CR1ノックアウトマウスでは, 常在 大腸菌の粘膜固有層からの採取と腸管リンパ節への 菌体輸送が特異的に完全に損なわれるが, パイエル 板での $\mathrm{M}$ 細胞経由の採取には影響が見られない. 病原性サルモネラ菌の場合にも, CX3CR1 ノック アウトマウスでは，侵襲性や非侵襲性に関わらず粘 膜樹状細胞への取り込みは顕著に減少しており, サ
ルモネラ菌の排除が抑制されている.

現在のところ, CX3CR1-フラクタルカインがど のようなメカニズムで, 樹状突起の形成に関与して いるかは不明である. CX3CR1 からのシグナルに より樹状細胞での ZO-1 などのタイトジャンクショ ンに局在するタンパク質の発現が誘導され上皮細胞 間隙への貫入を促進するのか ${ }^{28)}$, フラクタルカイン からのシグナルにより上皮細胞でのタイトジャンク ションが破壊されるのか, いずれにしても今後の重 要な課題である.

\section{その他の機能}

血小板には CX3CR1 が発現し, フラクタルカイ ンは血小板の活性化や細胞外基質への接着をひき起 こす29). フラクタルカインは, 神経幹細胞, アスト ロサイト, 神経細胞のアポトーシスを抑制すること が報告されている30). フラクタルカインは, basic FGF と同様に皮膚微小血管由来内皮細胞の管腔形 成を誘導し, 血管新生作用があると報告されてい る31).

\section{3. フラクタルカインと CX3CR1 の疾患との関わり}

\section{自己免疫疾患（関節リウマチなど）}

フラクタルカインと CX3CR1 は, 関節リウマチ (RA), 炎症性腸疾患, ループス腎炎, 多発性硬化 症などの自己免疫疾患において, その発症や病態に 関与していることが示唆されている32).

RA 患者の関節滑液中には, 分泌型フラクタルカ インが増加しており, 炎症細胞の活性化内皮細胞へ の接着や関節への浸潤あるいはサイトカイン産生に 関与していると考えられる，われわれは，RA患者 の末梢血では, $\mathrm{CD} 4^{+}$および $\mathrm{CD} 8^{+} \mathrm{T}$ 細胞におけ る CX3CR $1^{+}$perforin ${ }^{+}$の cytotoxic effector $\mathrm{T}$ 細胞 $\left(\mathrm{T}_{\mathrm{CE}}\right)$ が増加し, これらは IFN $-\gamma, \mathrm{TNF}-\alpha$ など Type I のサイトカインを強く産生することを見出 した ${ }^{33)}$. RA 滑膜では, 浸潤した $\mathrm{T}$ 細胞の一部, マ クロファージ, 樹状細胞, 滑膜繊維芽細胞などで CX3CR1 が発現している. 一方, フラクタルカイ ンは血管内皮細胞に加え, 滑膜繊維芽細胞やマクロ ファージでも発現が認められる. 臨床症状との関係 では, 滑液中の単球によるフラクタルカインの発現 と「朝のこわばり」, また滑液中の $\mathrm{T}$ 細胞における CX3CR1 の発現と「手指の腫脹」に相関があると の報告がある。一方, RA 患者の滑液には血管新生 作用があり, その作用は抗フラクタルカイン抗体に 
より消失することから， RA 滑膜の増生にフラクタ ルカインが関与していることが示唆される.

さらに最近われわれは, 抗フラクタルカイン抗体 投与によって, 関節リウマチの動物モデル CIA (Collagen-Induced arthritis) の発症や臨床症状を改 善し, 滑膜への炎症細胞の浸潤と骨破壊を抑制でき ることを明らかにした ${ }^{34)}$. CIA 滑膜組織では CX3CR1 はマクロファージと一部の $\mathrm{CD} 4^{+}$や $\mathrm{CD}^{+} \mathrm{T}$ 細胞で発現しており, CIA では正常マウ スと比較して関節局所でのフラクタルカインの発現 が上昇していた. しかしながら, 血清中コラーゲン 抗体価やコラーゲン刺激による脾臓 $\mathrm{T}$ 細胞からの IFN- $\gamma$ 産生には影響は見られなかった。抗フラク タルカイン抗体投与により, 蛍光標識脾臟マクロフ アージの炎症滑膜への浸潤が抑制されることから, 成熟単球の滑膜組織への浸潤抑制が主な作用メカニ ズムと考えられる.

\section{粥状動脈硬化症と虚血性心疾患}

フラクタルカインと CX3CR1 は心臓疾患との関 連も多数報告されている ${ }^{32)}$. アテローム性動脈硬化 症の病変部には, マクロファージ， $\mathrm{T}$ 細胞が多数浸 潤している35)。進行したヒト動脈硬化巣の血管でフ ラクタルカインの強い発現が認められ，浸潤したマ クロファージ, 泡沫細胞, 平滑筋細胞においてもフ ラクタルカインの発現が認められる ${ }^{36,37)}$ 。 また, 糖 尿病の合併症および移植心の冠動脈傷害の場合に も, フラクタルカインの血管内膜での発現と $\mathrm{CX} 3 \mathrm{CR} 1^{+}$細胞の浸潤が報告されている37).

CX3CR1 の 1 塩基多型（SNP）の解析から，249お よび 280 番目のアミノ酸に polymorphism が存在し,

I249 あるいは M280 ハプロタイプでは冠動脈疾患 の罹患率が低いとの興味深い報告もある15)。このメ カニズムは, CX3CR1 とフラクタルカインとの結 合親和性の低下により単球の血管内皮細胞への接着 活性が低下するためと考えられている38,39).

動脈硬化症のモデルである ApoE ノックアウト マウスでは, 病変部の平滑筋細胞でフラクタルカイ ンが強く発現している。CX3CR1/ApoEダブルノ ックアウトマウスでは, 血管壁へのマクロファージ の集積と動脈硬化巣が約 $50 \%$ に顕著に減少す る40,41). したがって，フラクタルカイン-CX3CR1 系は, 動脈硬化巣へのマクロファージの集積を誘導 して，発症に関与していると考えられる.

不安定プラークとCX3CR1 の関係も示唆されて
いる. アテローム性プラークの破裂は冠動脈血栓症 を誘発する ${ }^{42)}$. 最近の研究から, キラーリンパ球に よる内皮細胞傷害が不安定プラークの破裂に関与す ることが示唆されている ${ }^{43)}$. 不安定プラークには, $\mathrm{CD} 28^{-}$perforin $^{+}$の CD4 ${ }^{+} \mathrm{T}$ 細胞が選択的に浸潤し ており,これら $\mathrm{T}$ 細胞は, マクロファージを活性 化する IFN- $\gamma$ を大量に産生するのみならず, HSP60 を認識して CRP で活性化された内皮細胞の 傷害をひき起こす44). 不安定狭心症患者の未梢血で も, perforin ${ }^{+} \mathrm{CD} 4^{+} \mathrm{T}$ 細胞が著しく増加する。こ れら $\mathrm{T}$ 細胞は, 明らかに cytotoxic effector $\mathrm{T}$ 細胞 $\left(\mathrm{T}_{\mathrm{CE}}\right)$ であり $\mathrm{CX} 3 \mathrm{CR} 1$ を発現していると考えられ る. CX3CR1 を介した細胞接着や細胞傷害活性に より内皮細胞が破壊され, 不安定プラークの破壊が 生じる可能性が示唆される.

\section{臟器移植片拒絶反応}

臓器移植後の急性拒絶反応は, 免疫細胞の移植臓 器への顕著な浸潤や活性化と栄養血管の傷害により 生じると考えられている。，心臟移植患者の冠動脈に おいて, 血管傷害時にフラクタルカインの発現が認 められる37).アロ心移植動物モデルでは, 抗 CX3CR1 抗体が有意に拒絶を抑制し，CX3CR1ノ ックアウトマウスではサイクロスポリン A との併 用により $\mathrm{NK}$ 細胞や単球の浸潤と移植片の拒絶が抑 制される45,46)。 また，CX3CR1 ノックアウトマウ ス単独では, 移植片への NK 細胞の浸潤が抑制され ており, CX3CR1は, 特に NK 細胞の浸潤に重要 な役割を果たしていると考えられる。一方, 移植腎 の急性拒絶のリスクと, CX3CR1 の遺伝子型には 相関が認められていない47).

\section{癌と抗腫瘍効果}

フラクタルカイン遺伝子を導入した Lewis lung carcinoma がん細胞株をマウスに移植すると, 細胞 傷害性 $\mathrm{T}$ リンパ球によるがん特異的防御免疫が誘 導され，いわゆるがんワクチンとしての効果が認め られる48). フラクタルカインを発現するがん細胞に は CX3CR1 を発現する樹状細胞が誘引され接着す る. その結果, 樹状細胞の成熟と IL-12 の産生増 強が起こり, $\mathrm{T}$ 細胞の分化が強く誘導されがん免疫 が成立すると考えられる，さらに，樹状細胞， $\mathrm{CD}^{+} \mathrm{T}$ 細胞, $\mathrm{CD}^{+} \mathrm{T}$ 細胞のがん組織への浸潤が 六進し, 細胞傷害性 $\mathrm{T}$ リンパ球依存性のがん免疫 が強く発揮されるようになると考えられる。一方, 
EL-4 リンパ腫モデルに対する抗がん作用は，NK 細胞のみに依存しており $\mathrm{T}$ 細胞は関与していな (49). OVHM 卵巣腫瘍株の場合, フラクタルカイ ンの発現により免疫細胞の浸潤は増加するが, 血管 新生も誘導され効果が見られないとの報告もあ る50)。フラクタルカインは, がん抑制遺伝子 p53 の下流ターゲット遺伝子としても同定されてお り ${ }^{10)}$, 異常な細胞で発現するようにプログラムされ た内在性の危険シグナルとして機能している可能性 がある.

最近, CX3CR1 は前立腺がんに発現し, フラク タルカインは骨髄内皮細胞と骨芽細胞で発現してい ることが報告された ${ }^{51)}$. 生理的流速下での前立腺が ん細胞の骨䯣内皮細胞への接着は抗フラクタルカイ ン抗体で阻害される。骨芽細胞は分泌型フラクタル カインを産生し前立腺がん細胞の遊走を誘導する. さらに, フラクタルカインは, 前立腺がん細胞にお いて PI-3 キナーゼ/Akt/GSK3ßなどの細胞生存に 関わるシグナルを活性化することも示されている. このように，フラクタルカインの前立腺がん細胞の 骨転移への関与が示唆される。

\section{その他の疾患}

腎炎患者の腎臓では, 浸潤した NK 細胞, $\mathrm{T}$ 細 胞, マクロファージにCX3CR1 の発現が認められ る52). 系球体腎炎動物モデルでは, 糸球体内皮細胞 でフラクタルカインの発現が強く誘導され， CX3CR1 は糸球体に浸潤した炎症細胞に発現して いる. 抗 CX3CR1 抗体投与により, 炎症細胞の浸 潤が抑制され腎機能が改善する53). AIDS 患者のリ ンパ節では, 樹状細胞や形質細胞でフラクタルカイ ンが過剩発現しており, 末梢血中の CX3CR1 の発 現率は, AIDS の進行度と相関する ${ }^{54)}$. CX3CR1 I249-M280 のハプロタイプを持つ HIV 感染者では, AIDS の進行が早い14). 抗フラクタルカイン抗体に は，抗腫瘍効果に影響を与えることなく急性移植片 対宿主病による致死的な腸管傷害および ConA 誘 導肝傷害を抑制する効果も見られている. その他, 肺高血圧症, 虚血再灌流傷害, 乾癬, アトピー性皮 膚炎への関与も示唆されている.

\section{おわりに}

CX3CR1 は, エフェクターキラーリンパ球や成 熟単球・マクロファージと骨髄系樹状細胞など，い わゆる最終分化・成熟した細胞に発現するユニーク
な受容体である，これら細胞は，関節リウマチや喘 息などの慢性炎症疾患の際に血液中に増加する集団 であり, 臨床病態と密接に関与している。 CX3CR1-フラクタルカイン系の慢性炎症における 役割の解明は, CX3CR1+細胞が末梢血中で増加す る意義や病態形成への関与を含め, 今後の重要な課 題である.すでに様々な疾患において, フラクタル カイン-CX3CR1 系の関与を示唆する結果が蓄積さ れつつある. また, 中和抗体やノックアウトマウス の結果から, フラクタルカイン-CX3CR1 系の機能 阻害により疾患制御が可能であることが明らかとな ってきた. 今後, フラクタルカイン-CX3CR1 系の 機能阻害による慢性炎症疾患治療への応用が期待さ れる. 従来の免疫抑制剂, 酵素阻害剂, 抗サイトカ イン療法などで, 病変部における高濃度の標的分子 を阻害しようとすると, 正常部位における低濃度で の生理的活性をも阻害してしまう危険性がある。ケ モカイン受容体阻害剂は, 病変部への細胞浸潤を時 空間的に制御することで, 生理的機能に影響を及ぼ さず局所での過剩な反応を選択的に抑制する安全性 の高い薬剤となることが期待される.

\section{文献}

1) Butcher E, Williams M, Youngman $K$, et al. : Lymphocyte trafficking and regional immunity. Adv Immunol. 72 : 209-253, 1999.

2) Butcher $E$ : Leukocyte-endothelial cell recognition : three (or more) steps to specificity and diversity. Cell 67 : 1033-1036, 1991.

3）今井俊夫：ケモカインと接着分子のハイブ リッド分子 fractalkine. Annual review 免疫 2000, 東京, 中外医学社, 186-192, 1999.

4) Umehara H, Bloom E, Okazaki T, et al. : Fractalkine and vascular injury. Trends Immunol 22 : 602-607, 2001.

5) Bazan Jf, Bacon Kb, Hardiman G, et al. : A new class of membrane-bound chemokine with a CX3C motif. Nature 385 : 640-644, 1997.

6) Yoshie $\mathrm{O}$, Imai $\mathrm{T}$, and Nomiyama $\mathrm{H}$ : Chemokines in immunity. Adv Immunol 78 : 57-110, 2001.

7) Fong Am, Erickson $\mathrm{Hp}$, Zachariah Jp, et al. : Ultrastructure and function of the fractalkine mucin domain in $\mathrm{CX}$ (3) C chemokine domain presentation. J Biol Chem 275 : 3781-3786, 2000.

8) Imaizumi $T$, Yoshida $H$, and Satoh $K$ : Regulation of $\mathrm{CX} 3 \mathrm{CL} 1 /$ fractalkine expression in en- 
dothelial cells. J Atheroscler Thromb $11: 15-$ 21, 2004.

9) Fraticelli P, Sironi M, Bianchi G, et al. : Fractalkine (CX3CL1) as an amplification circuit of polarized Th1 responses. J Clin Invest 107 : 1173-1181, 2001.

10) Shiraishi K, Fukuda $S$, Mori T, et al. : Identification of fractalkine, a CX3C-type chemokine, as a direct target of p53. Cancer Res 60 : 37223726, 2000.

11) Tsou $\mathrm{Cl}$, Haskell $\mathrm{Ca}$, and Charo If : Tumor necrosis factor-alpha-converting enzyme mediates the inducible cleavage of fractalkine. $J$ Biol Chem 276 : 44622-44626, 2001.

12) Garton $\mathrm{Kj}$, Gough $\mathrm{Pj}$, Blobel $\mathrm{Cp}$, et al. : Tumor necrosis factor-alpha-converting enzyme (ADAM17) mediates the cleavage and shedding of fractalkine (CX3CL1). J Biol Chem 276 : 37993-38001, 2001.

13) Imai $T$, Hieshima $K$, Haskell $C$, et al. : Identification and molecular characterization of fractalkine receptor $\mathrm{CX} 3 \mathrm{CR} 1$, which mediates both leukocyte migration and adhesion. Cell 91 : 521-530, 1997.

14) Faure S, Meyer L, Costagliola D, et al. : Rapid progression to AIDS in HIV+ individuals with a structural variant of the chemokine receptor CX3CR1. Science 287 : 2274-2277, 2000.

15) Moatti D, Faure S, Fumeron F, et al. : Polymorphism in the fractalkine receptor CX3CR1 as a genetic risk factor for coronary artery disease. Blood 97 : 1925-1928, 2001.

16) Goda $S$, Imai $T$, Yoshie $O$, et al. : $\mathrm{CX} 3 \mathrm{C}^{-}$ chemokine, fractalkine-enhanced adhesion of THP-1 cells to endothelial cells through integrin-dependent and -independent mechanisms. J Immunol 164 : 4313-4320, 2000.

17) Hundhausen $C$, Misztela $D$, Berkhout Ta, et al. : The disintegrin-like metalloproteinase ADAM10 is involved in constitutive cleavage of CX3CL1 (fractalkine) and regulates CX3CL1mediated cell-cell adhesion. Blood 102 : 11861195, 2003.

18) Fong Am, Robinson La, Steeber Da, et al. : Fractalkine and CX3CR1 mediate a novel mechanism of leukocyte capture, firm adhesion, and activation under physiologic flow. $J$ Exp Med 188 : 1413-1419, 1998.

19) Fong Am, Alam Sm, Imai $T$, et al. : CX3CR1 tyrosine sulfation enhances fractalkine-induced cell adhesion. J Biol Chem 277 : 19418-19423,
2002.

20) Nishimura $M$, Umehara $H$, Nakayama $T$, et al. : Dual functions of fractalkine/CX3C ligand 1 in trafficking of perforin $+/$ granzyme $\mathrm{B}+$ cytotoxic effector lymphocytes that are defined by CX3CR1 expression. J Immunol 168 : 61736180, 2002.

21) Yoneda $O$, Imai $T$, Goda $S$, et al. : Fractalkinemediated endothelial cell injury by NK cells. $J$ Immunol 164 : 4055-4062, 2000.

22) Yoneda $O$, Imai $T$, Nishimura $M$, et al. : Membrane-bound form of fractalkine induces IFNgamma production by NK cells. Eur J Immunol $33: 53-58,2003$.

23) Geissmann F, Jung S, and Littman Dr : Blood Monocytes Consist of Two Principal Subsets with Distinct Migratory Properties. Immunity 19: 71-82, 2003.

24) Ancuta P, Rao R, Moses A, et al. : Fractalkine preferentially mediates arrest and migration of CD16+ monocytes. J Exp Med 197 : 17011707, 2003.

25) Sunderkotter $\mathrm{C}$, Nikolic $\mathrm{T}$, Dillon $\mathrm{Mj}$, et al. : Subpopulations of mouse blood monocytes differ in maturation stage and inflammatory response. J Immunol 172 : 4410-4417, 2004.

26) Jung S, Aliberti J, Graemmel P, et al. : Analysis of fractalkine receptor CX (3) CR1 function by targeted deletion and green fluorescent protein reporter gene insertion. $\mathrm{Mol}$ Cell Biol 20 : 4106-4114, 2000.

27) Niess Jh, Brand S, Gu X, et al. : CX3CR1mediated dendritic cell access to the intestinal lumen and bacterial clearance. Science 307 : 254-258, 2005.

28) Rescigno M, Urbano M, Valzasina B, et al. : Dendritic cells express tight junction proteins and penetrate gut epithelial monolayers to sample bacteria. Nat Immunol 2 : 361-367, 2001.

29) Schafer A, Schulz C, Eigenthaler $M$, et al. : Novel role of the membrane-bound chemokine fractalkine in platelet activation and adhesion. Blood 103 : 407-412, 2004.

30) Meucci O, Fatatis A, Simen Aa, et al. : Chemokines regulate hippocampal neuronal signaling and gp120 neurotoxicity. Proc Natl Acad Sci U S A 95 : 14500-14505, 1998.

31) Volin Mv, Woods Jm, Amin Ma, et al. : Fractalkine : a novel angiogenic chemokine in rheumatoid arthritis. Am J Pathol 159 : 1521-1530, 2001. 
32) Umehara H, Bloom Et, Okazaki T, et al. : Fractalkine in Vascular Biology : From Basic Research to Clinical Disease. Arterioscler Thromb Vasc Biol 24 : 34-40, 2004.

33) Nanki $T$, Imai $T$, Nagasaka $K$, et al. : Migration of CX3CR1-positive $\mathrm{T}$ cells producing type 1 cytokines and cytotoxic molecules into the synovium of patients with rheumatoid arthritis. Arthritis Rheum 46 : 2878-2883, 2002.

34) Nanki $T$, Urasaki $Y$, Imai $T$, et al. : Inhibition of fractalkine ameliorates murine collagen-induced arthritis. J Immunol 173 : 7010-7016, 2004.

35) Hansson Gk : Immune Mechanisms in Atherosclerosis. Arterioscler Thromb Vasc Biol 21 : 1876-1890, 2001.

36) Greaves Dr, Hakkinen $\mathrm{T}$, Lucas Ad, et al. : Linked chromosome 16q13 chemokines, macrophage-derived chemokine, fractalkine, and thymus- and activation-regulated chemokine, are expressed in human atherosclerotic lesions. Arterioscler Thromb Vasc Biol 21 : 923-929, 2001.

37) Wong Bwc, Wong $\mathrm{D}$, and Mcmanus Bm : Characterization of fractalkine (CX3CL1) and CX3CR1 in human coronary arteries with native atherosclerosis, diabetes mellitus, and transplant vascular disease. Cardiovascular Pathology 11 : 332-338, 2002.

38) Mcdermott Dh, Fong Am, Yang Q, et al. : Chemokine receptor mutant CX3CR1-M280 has impaired adhesive function and correlates with protection from cardiovascular disease in humans. J Clin Invest 111 : 1241-1250, 2003.

39) Mcdermott Dh, Halcox Jp, Schenke Wh, et al. : Association between polymorphism in the chemokine receptor CX3CR 1 and coronary vascular endothelial dysfunction and atherosclerosis. Circ Res 89 : 401-407, 2001.

40) Lesnik P, Haskell Ca, and Charo If : Decreased atherosclerosis in CX3CR1 - / - mice reveals a role for fractalkine in atherogenesis. J Clin Invest 111 : 333-340, 2003.

41) Combadiere C, Potteaux S, Gao Jl, et al. : Decreased atherosclerotic lesion formation in CX3CR1/apolipoprotein E double knockout mice. Circulation 107 : 1009-1016, 2003.

42) Greaves Dr and Channon Km : Inflammation and immune responses in atherosclerosis. Trends in Immunology 23 : 535-541, 2002.

43) Nakajima $\mathrm{T}$, Schulte $\mathrm{S}$, Warrington $\mathrm{Kj}$, et al. : T-Cell-Mediated Lysis of Endothelial Cells in
Acute Coronary Syndromes. Circulation 105 : 570-575, 2002.

44) Zal B, Kaski Jc, Arno G, et al. : Heat-shock protein 60-reactive CD4+CD28null $\mathrm{T}$ cells in patients with acute coronary syndromes. Circulation 109 : 1230-1235, 2004.

45) Haskell Ca, Hancock Ww, Salant $\mathrm{Dj}$, et al. : Targeted deletion of CX (3) CR1 reveals a role for fractalkine in cardiac allograft rejection. $J$ Clin Invest 108 : 679-688, 2001.

46) Robinson La, Nataraj C, Thomas Dw, et al. : A role for fractalkine and its receptor (CX3CR1) in cardiac allograft rejection. J Immunol 165 : 6067-6072, 2000.

47) Abdi R, Tran Tb, Sahagun-Ruiz A, et al. : Chemokine receptor polymorphism and risk of acute rejection in human renal transplantation. J Am Soc Nephrol 13 : 754-758, 2002.

48) Guo J, Zhang M, Wang B, et al. : Fractalkine transgene induces $\mathrm{T}$-cell-dependent antitumor immunity through chemoattraction and activation of dendritic cells. Int J Cancer 103 : 212220, 2003.

49) Lavergne E, Combadiere B, Bonduelle O, et al. : Fractalkine mediates natural killer-dependent antitumor responses in vivo. Cancer Res 63 : 7468-7474, 2003.

50) Gao Jq, Tsuda Y, Katayama K, et al. : Antitumor Effect by Interleukin-11 Receptor alpha-Locus Chemokine/CCL27, Introduced into Tumor Cells through a Recombinant Adenovirus Vector. Cancer Res 63 : 4420-4425, 2003.

51) Shulby $\mathrm{Sa}$, Dolloff $\mathrm{Ng}$, Stearns $\mathrm{Me}$, et al. : CX3CR1-fractalkine expression regulates cellular mechanisms involved in adhesion, migration, and survival of human prostate cancer cells. Cancer Res 64 : 4693-4698, 2004.

52) Segerer S, Hughes E, Hudkins K1, et al. : Expression of the fractalkine receptor (CX3CR1) in human kidney diseases. Kidney Int 62 : 488495, 2002.

53) Feng L, Chen S, Garcia Ge, et al. : Prevention of crescentic glomerulonephritis by immunoneutralization of the fractalkine receptor CX3CR1 rapid communication. Kidney Int 56 : 612-620, 1999.

54) Foussat A, Bouchet-Delbos L, Berrebi D, et al. : Deregulation of the expression of the fractalkine/fractalkine receptor complex in HIV-1infected patients. Blood 98 : 1678-1686, 2001. 